\title{
Sweetened Packaged Beverage Purchase Intention and Behavior based on Subjective Norm, Perceived Risk, and Perceived Value
}

\section{Maverick Khofanda and Prawira Fajarindra Belgiawan}

School of Business and Management, Institut Teknologi Bandung, Indonesia

\section{Abstract}

In the recent decade, sweetened packaged beverages have risen in Indonesia. Several studies have verified its adverse effects on health, and Indonesian media publish it frequently on their portals. It is necessary to investigate the relationship between the product purchase intention and frequency, with people's perceived risk on the product and their exposure from media - including about the products' adverse effects. This research surveyed 254 respondents via online questionnaire quantitatively. Then,

Corresponding Author: Maverick Khofanda maverick.khofanda@sbmitb.ac.id

Received: 7 August 2018 Accepted: 15 September 2018 Published: 22 October 2018

Publishing services provided by Knowledge

(c) Maverick Khofanda and Prawira Fajarindra

Belgiawan. This article is distributed under the terms of the Creative Commons

Attribution License, which permits unrestricted use and redistribution provided that the original author and source are credited.

Selection and Peer-review under the responsibility of the ICE-BEES 2018 Conference Committee.

\section{S OPEN ACCESS} principal component analysis is conducted to construct the perceived risk, perceived value, and subjective norm. Afterward, ordinal logistic regression is deployed to measure whether there is a significant relationship between those mentioned factors toward purchase intention. Finally, we conducted ordinary least square to test the significant relationship between intention and actual purchase behavior/frequency. It is found that only perceived value on the product and respondents' reference group opinion on consuming the product significantly affects their purchase intention and actual purchase behavior. This means, neither perceived risk on the product nor media exposure affects respondents' purchase intention and behavior. These findings are encouraging for sweetened packaged beverages company, while health officials and activists may find these results unfavorable.

Keywords: sweetened packaged beverages; theory of planned behavior; purchase intention; perceived risk; perceived value; mass media

\section{Introduction}

Beverage product has been in Indonesia's consumer product scene for a long time. Since previous decade, many brands have entered, and some also have phased out from the market, which ranges from juice, ionized drink, soy milk, coffee, and tea. (Minute Maid in 2008, IsoPlus in 2016, Naraya Soya, Luwak White Koffie in 2012, TOP Coffee in 2012, Teh Gelas in 2007, Teh Pucuk in 2011) [1-6]. 
One of the most common ingredients in Indonesian beverages is sugar. There are some types of sugar, and the most common ones in beverages are fructose, glucose, and sucrose. Fructose intake is associated with risk of type 2 diabetes [7], while sucrose-sweetened beverages is found to increase ectopic fat accumulation and lipid compared to a few other beverages, which means daily intake can increase the risk of metabolic and cardiovascular diseases [8]. Other studies show that sugar-sweetened beverages are correlated with a risk of obesity, type 2 diabetes, and cardiovascular disease $[9,10]$. World health organization / WHO also recommends to reduce consumption of free sugar to less than $10 \%$ of total energy intake [11]

In Indonesia's major mass media, sugar is explicitly and implicitly defined as a cause of diabetes, such as in Okezone, Merdeka, Tribunnews, and Kompas [12-15]. Meanwhile, studies suggest that mass media can influence health services utilization and health behavior change [16-18]. Thus, we can infer that these media may have influence toward customers' behavior on sugar consumptions, especially on sweetened beverages.

Behaviorally relevant reference group - such as family or friends and peers at university- has been found to affect behavior of individuals, such as intentions to engage in regular exercises [19] and eating healthy foods [20]. However, reference group behaviors also have been found to affect individuals to binge-drink [21].

The pervasiveness of sugar in beverages, mass media perception and customer perception of sugar in beverages are an issue for beverage producers, especially when deciding the appropriate sugar amount. Do the customers care about the sugar amount in beverages and how it affects their health? Or do they care more about the flavor and the thirst-quenching properties? This research sought to answer these questions, which could assist beverage producers in deciding the ideal sugar amount for customers. Beside producers, health researcher could also make use of this research for consumer behavior.

From our discussion above, there is an issue whether sugar-sweetened beverages' - especially sweetened packaged beverages' - purchase intention and behavior are affected by customers' perception of its risk, customers' perception of its value, and the opinion of others/external opinion for Indonesian customers, which would be the main focus of this research.

This paper is structured in the following way: Following this introduction, the next part of this paper discusses sugar's history \& risks and the theoretical basis for this research. In the third part, we present the research design, sampling \& measurement methods, and the methods to analyze the collected data. The fourth part of this paper 
analyzes and discusses the implication of the analysis results. In the final part, we conclude from the results and give recommendations based on them.

\section{Literature Review}

The word 'sugar' is commonly defined as sweet, soluble carbohydrates, which are used frequently in food and beverages. Simple sugar is called monosaccharides. It is the fundamental form of carbohydrates and cannot be hydrolyzed to simpler compounds. Monosaccharides examples are glucose/dextrose, fructose, and galactose. While disaccharides are made from two monosaccharides. Common examples of disaccharides are maltose, lactose, and sucrose. Sucrose can be hydrolyzed into fructose and glucose, and it is the commonly used sugar, thus called table sugar. It is also known as granulated sugar. Longer sugar chains are called polysaccharides or oligosaccharides.

Sugar consumption has been traced back to 10,000 years ago in New Guinea [22], where sugar cane was eaten raw and treated like an elixir by the people. By 500 AD, sugar cane has been processed to a powder in India as a medicine for various purposes, ranging from a headache to impotence. Then, sugar refinement spread to Persia, and later when the Arabs conquered the area, they spread sugar and the technology of its production. Sugar then spread to Europe, but sugar cane requires tropical rainy fields to flourish, thus sugar was labeled as a spice in Europe. The age of exploration is said to be a hunt for fields where sugarcane could grow and prosper. With Columbus planting the first sugarcane in Hispaniola in the Caribbean, thus begins the age of slave-produced sugar, which decades and decades later sparks various revolts in the New World.

Despite the grim story behind sugar production, it sparks the boom in sugar consumption, from 4 pounds per man a year in 1700, to 100 pounds a year by 1900 [22]. Today, the average sugar consumed by each person each year is 53 pounds or 24 kilograms, and 73 pounds or 33 kilograms in developed countries. [23]. Mechanized sugar production was documented for the first time in 1768 in Jamaica [24]. Sugar we usually consume is mostly taken from sugarcane and sugar beet, which was produced approximately 2,010.4 million tons and 277.4 million tons respectively in 2014 [25]. In the US, however, high-fructose corn syrup (HFCS) fills the sweetening role of table sugar / refined sugar, as shown in Figure 1 [26]. In the modern world nowadays, research on sugar is carried out to find out whether it relates to diseases. Studies show significant relations between fructose - including sucrose/table sugar because it contains fructose - with illnesses such as coronary heart disease and type-2 diabetes 
$[9,27]$. In Indonesia, many major mass media in Indonesia define sugar explicitly and implicitly as a cause of diabetes, as mentioned in the introduction.

According to Hochbaum, et.al's [28] health belief model, perceived susceptibility and perceived seriousness of people toward risk of getting an illness can affect the likeliness of people to take action to avoid the illness. With the general knowledge of sugar risk toward diabetes and media exposure on the subject, Indonesians are expected to have some level of perceived susceptibility and seriousness if they frequently consume sugar-sweetened beverages, especially sweetened packaged beverages.

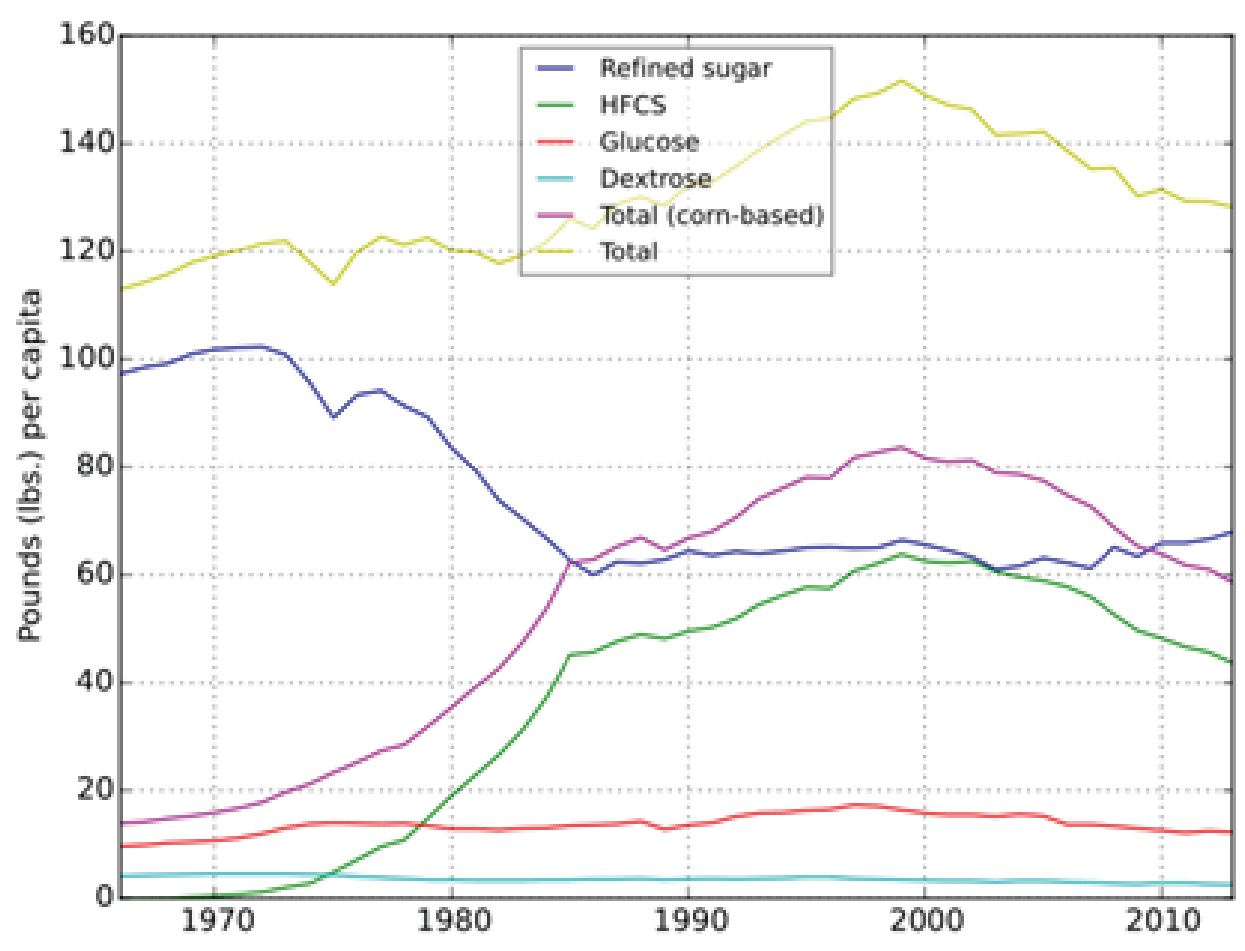

Figure 1: US sweetener consumption. [26].

Perceived susceptibility represents everyone's own perception of his/her likeliness to contract a certain disease. In one end of the spectrum, the person thinks that he/she is very likely to contract a certain disease. In the other extreme, the person believes that he/she is nearly impossible to contract the disease. While perceived seriousness refers to the person's belief regarding the effects on his/her state of affair if given a disease or condition. These losses could manifest as discomfort, loss of time, financial burdens, and family and relationships difficulties. Hochbaum, et.al. [28] state the importance to include emotional and financial burdens when considering the seriousness of a certain disease or condition. Perceived value is "the consumer's overall 
assessment of the utility of a product based on perceptions of what is received and what is given" [29]. Perceived value also has been found to have a linkage toward behavioral intentions, such as customer's loyalty and customer's satisfaction level [30]. In the beverage industry, thirst-quenching, taste, and lifestyle are oftentimes the reasons people buy beverage products. It's expected that the more value the customer perceives on sweetened packaged beverages, the higher their intention to buy them.

According to Ajzen [31], subjective norm is "the perceived social pressure to engage or not to engage in a behavior". Based on various research, reference group and mass media have been known to shape the norm and consequently, affects the intention and behavior of the people. The reference group is the group that individuals refer to when evaluating themselves, whether it's quality, circumstance, value, behavior, and attitude (Thompson Hickey 2004). Relevant reference group has been found to affect behaviors, such as when engaging regular exercises [19], eating healthy foods [20], and binge-drinking [21].

In several studies, mass media have been found to indirectly affect individuals' behavior. Gunther, et al. [32] have found significant indirect influence from mass media toward the adolescent's behavior, via its effect on perceived peer norms. Adolescents who are exposed to more sexual contents are also have been found to report greater intentions to engage in sexual intercourse and sexual intentions [33]. Therefore, it is expected that the more positive exposure the customer gets regarding sugar-sweetened beverages from reference group and mass media - which represents norms, the higher the customer's intention to buy the product. And the more the customer gets negative exposure regarding sugar-sweetened beverages from reference group and mass media, the less their intention to buy sugar-sweetened beverages. Therefore, for this research the hypotheses proposed can be seen in Figure 2.

Rectangle boxes represents observed variables, while ellipses represent latent variables. Observed variables are directly acquired from observation, but latent variables can't be measured directly. So, latent variables are constructed by some observed variables. The arrows from the ellipses (latent variables) to the rectangles at the left represents this relationship, where observed variables construct a latent variable. For example, 'perceived value' is constructed by 'thirst-quenching', 'taste', and 'lifestyle'. Meanwhile, the arrows from the ellipses to intention, and intention \& sociodemographic to actual behavior represents the hypotheses discussed above, and not construct relationship. (for example, 'perceived value' is hypothesized to be related to 


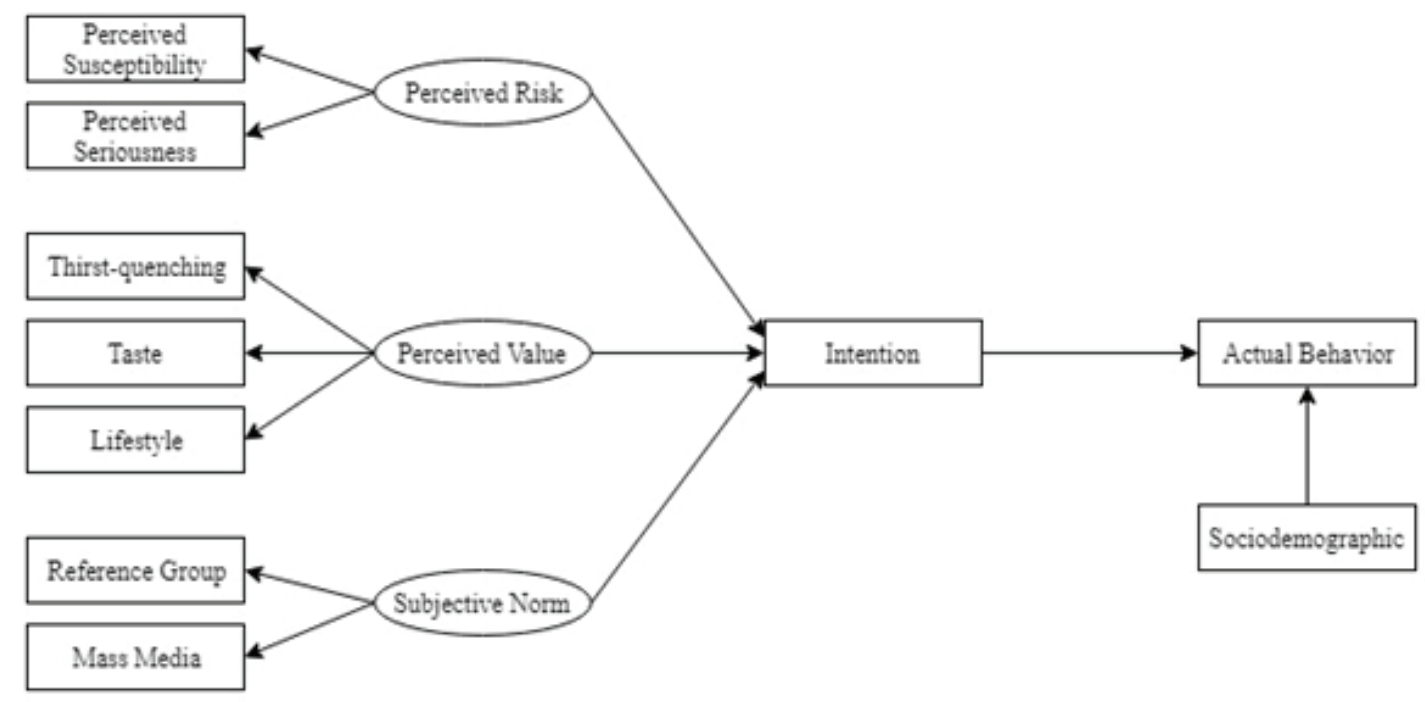

Figure 2: Proposed Framwork.

'intention'). Sociodemographic is also tested toward actual behavior to test if gender, age, or monthly spending also relates with actual behavior.

\section{Methodology}

\subsection{Research design}

We asked respondents who reside in Indonesia and exclude everyone below 15 years old, because most Indonesians had consumed sweetened packaged beverage at some point at their life, however, we want to make sure the respondents have enough comprehending capability to understand the questions in the survey. Meanwhile, the sampling is based on a discussion about ordinal logistic regression and its sample size by Simon [34] on a journal related to the method [35], Simon [34] recommends a sample size between 100 to 107. We used data from 254 respondents, so the data should be adequate quantitatively. The sampling technique for this research is non-probability sampling method, especially convenience sampling. This method is chosen due to the constraints of cost, time, and resources to do the research. Snowball technique would also be employed in the research to reach inaccessible population.

This questionnaire uses a 7-point Likert scale for all the questions as the measurement method, where a higher number indicates higher agreement and a lower number indicates higher disagreement, with seven indicates 'strongly agree', four indicates neutral, and one indicates 'strongly disagree'. Sociodemographic data uses various measurement method. Table 1 shows the details of the variables, sub-variables, and 
reference used in this research. Further detail can be seen in Appendix A. We constructed factors based on the theories discussed in the previous chapter. Perceived risk is hypothetically constructed by six variables, comprised of the respondents' perceived susceptibility if he/she consumes sweetened packaged beverages and the perceived seriousness if he/she ever contracts a disease because of consuming the product. Perceived seriousness is divided into a few dimensions: finance, un-comfortability, time lost, friends relation, a family relation.

Perceived value factor is about the respondents' preference in buying sweetened packaged beverages, which hypothetically constructed by three variables: thirstquenching, taste, and lifestyle. Subjective norm is about the respondents' perception of how their reference group (the people important for them) might think about the respondents' action of consuming sweetened packaged beverages. It is argued that mass media can indirectly influence individuals' behavior, especially on the perceived reference group norms. Intention and actual behavior variables are directly derived from Ajzen's [31] Theory of Planned Behavior model, where intention is about the respondents' willingness to consume sweetened packaged beverages, while actual behavior is about the respondent's actual frequency of buying the product.

\subsection{Data analysis technique}

At first, we performed Cronbach's Alpha to do the reliability test. The result is presented is as follows. Perceived risk Cr. Alpha is 0.82 while perceived value Cr. Alpha is 0.629 and subjective norm is 0.145 . The test shows very poor alpha, especially in 'subjective norm - media'. This means confirmatory factor analysis cannot be applied due to the very low result in reliability testing. Thus, we proceeded to do exploratory factor analysis to find out the proper structure underlying the data. Principal component analysis (PCA) with varimax rotations is chosen as the exploratory factor analysis method. PCA is a data reduction technique that processes a set of correlated variables to a new set of fewer, uncorrelated variables [37].

After the new construct variables are obtained from PCA, we would test how the variables might influence intention. The observed variables and intention data use Likert-scale, and there has been debate whether Likert-scale is ordinal or interval data [38]. We utilized ordinal logistic regression (ordinal logit) for this significance test because we argue that the interval between Likert-scale are unequal. Thus, ordinal logit is used because it is more proper for ordinal data than ordinary least square 
TABLE 1: Variables list.

\begin{tabular}{|c|c|c|}
\hline Variable & Reference & Sub-variable \\
\hline \multirow[t]{6}{*}{ Perceived Risk } & Hochbaum, et.al [28] & Susceptibility \\
\hline & & Seriousness: Finance \\
\hline & & Seriousness: Uncomfortability \\
\hline & & Seriousness: Time Lost \\
\hline & & Seriousness: Friend Relation \\
\hline & & Seriousness: Family Relation \\
\hline \multirow[t]{3}{*}{ Perceived Value } & (none)* & Thirst quenching \\
\hline & & Taste \\
\hline & & Trendy \\
\hline \multirow[t]{5}{*}{ Subjective Norm (SN) } & Belgiawan, et al. [36] & Reference Group: Approval \\
\hline & & Reference Group: Encouragement \\
\hline & Gunther, et al. [32] & Media Exposure: Advertisement \\
\hline & L’Engle, et al. [33] & Media Exposure: Product Benefits / Pros \\
\hline & & Media Exposure: Product Harms / Cons \\
\hline Intention & Ajzen [31] & Intention \\
\hline Actual Behavior & Ajzen [31] & Behavior \\
\hline \multirow[t]{3}{*}{ Sociodemographic } & (none) & Gender (Male:0; Female: 1) \\
\hline & & Age \\
\hline & & Monthly Spending \\
\hline
\end{tabular}

(OLS). However, it is important to note that regression method is not in itself implying causation. Regression is a method where independent variable is tested against the dependent variable while other independent variable(s) are held equal (ceteris paribus), thus if one tested variables is significant, so an increase of that variables could be translated into increase/decrease of the dependent variable.

Then, we did another significance test toward actual behavior from intention and sociodemographic data. Most of the data in this test are not ordinal: gender is dichotomous, while actual behavior, age, and monthly spending are interval data. Actual behavior and monthly spending data were processed to interval data, which are presented in Appendix A. Because of the data types explained above, OLS is used to test the significance toward actual behavior.

\section{Data and Analysis}




\subsection{Descriptive statistic}

This research involves 254 respondents and we asks their gender, age, monthly spending, and job. This research would use all sociodemographic data, except jobs for deeper analysis later. This can be seen in Table 2.

Sociodemographic Descriptive Statistics

TABLE 2: Sociodemographic descriptive statistics.

\begin{tabular}{|l|c|c|}
\hline Variable & Mean & Std. Deviation \\
\hline Gender (o: male; 1:female) & 0.510 & 0.501 \\
\hline Age & 22.650 & 6.324 \\
\hline Monthly Expense (in million IDR) & 2.724 & 3.625
\end{tabular}

The gender is fairly equally distributed between male and females. While the age data is centered slightly over university age. This is because it is more convenient to get data from university students. Lastly, the monthly expense is well below Bandung City UMK (UMK is a city's minimum wage (Upah Minimum Kota) stated by the government) of IDR 3.09 million [39] or Jakarta UMP (UMP is a province's minimum wage (Upah Minimum Provinsi) stated by the government) of IDR 3.65 million [40]. It is likely because many of the respondents are students, which many of them still depends on their parents. However, the standard deviation for the monthly expense is very high, which means a high spread across the spectrum. It is important to note that monthly expense question uses ordinal categories which later converted to interval data.

\subsection{Principal component analysis}

To construct the latent variables, we would use PCA with varimax rotations as the exploratory factor analysis method. The result is presented in the following table, the variables in the first column are based on the research framework, while the variables in the third column are based on the PCA result. Following analyses would use variables based on PCA rather than the research framework and sometimes would be referred using their variable code instead of the regular variable name because they are relatively shorter. The result can be seen in Table 3.

Perceived risk factor is split into two factors: PRISK_1 and PRISK_2. Perceived value from PCA result does not differ from the theoretical framework and would be referred as PVAL. Subjective norm factor is split into 3: SN_RG, SN_ADS, and SN_PROCON. Sociodemographic data is regressed toward actual behavior, together with intention. 
TABLE 3: PCA-based variables.

\begin{tabular}{|c|c|c|c|}
\hline $\begin{array}{l}\text { Theoretical } \\
\text { framework-based } \\
\text { variables }\end{array}$ & Sub-Variable & PCA-based variables & Variable Code \\
\hline \multirow[t]{6}{*}{ Perceived Risk } & Susceptibility & Perceived Risk 1 & PRISK_1 \\
\hline & Seriousness - Financial & & \\
\hline & Seriousness - Uncomfortability & & \\
\hline & Seriousness - Time lost & Perceived Risk 2 & PRISK_2 \\
\hline & Seriousness - Friend relations & & \\
\hline & Seriousness - Family relations & & \\
\hline \multirow[t]{3}{*}{ Perceived Value } & Thirst-quenching & Perceived Value & PVAL \\
\hline & Taste & & \\
\hline & Lifestyle & & \\
\hline \multirow[t]{5}{*}{ Subjective Norm } & Reference Group: Approval & $\begin{array}{l}\text { Subjective Norm - } \\
\text { Reference Group }\end{array}$ & SN_RG \\
\hline & Reference Group: Encouragement & & \\
\hline & Media Exposure: Advertisements & Ads Exposure & SN_ADS \\
\hline & Media Exposure: Product Benefits & $\begin{array}{l}\text { Exposure to } \\
\text { Sweetened } \\
\text { Packaged } \\
\text { Beverages' Benefits } \\
\text { and Harms }\end{array}$ & SN_PROCON \\
\hline & Media Exposure: Product Harms & & \\
\hline
\end{tabular}

For further detail about how the sub-variables are arranged within the new variables, readers can refer to the Figure 3.

\subsection{Factors influencing intention}

After finding the proper factors (latent variables) by PCA, ordinal logit is performed with intention being the dependent variable. The result can be seen in Table 4. It was found that PVAL (Perceived Value) and SN_RG (Subjective Norm: Reference Group) has p-value lower than.05 and beta higher than o, which means they significantly affect intention in the positive direction. This means if the respondents' perceived value toward sweetened packaged beverages is higher, the intention to buy the product would also be higher. The intention to buy sweetened packaged beverages would also be higher if the respondents' reference group - the most important people for the respondents - agree and/or support the respondent buying the product.

Meanwhile, intention to buy sweetened packaged beverages is not found to be significantly influenced by PRISK_1, PRISK_2 (Perceived Risk), SN_ADS (Ads Exposure), and SN_PROCON (Product Benefit/Harms Exposure). It's It is interesting that respondents' perceived risk toward sweetened packaged beverages and media exposure - 


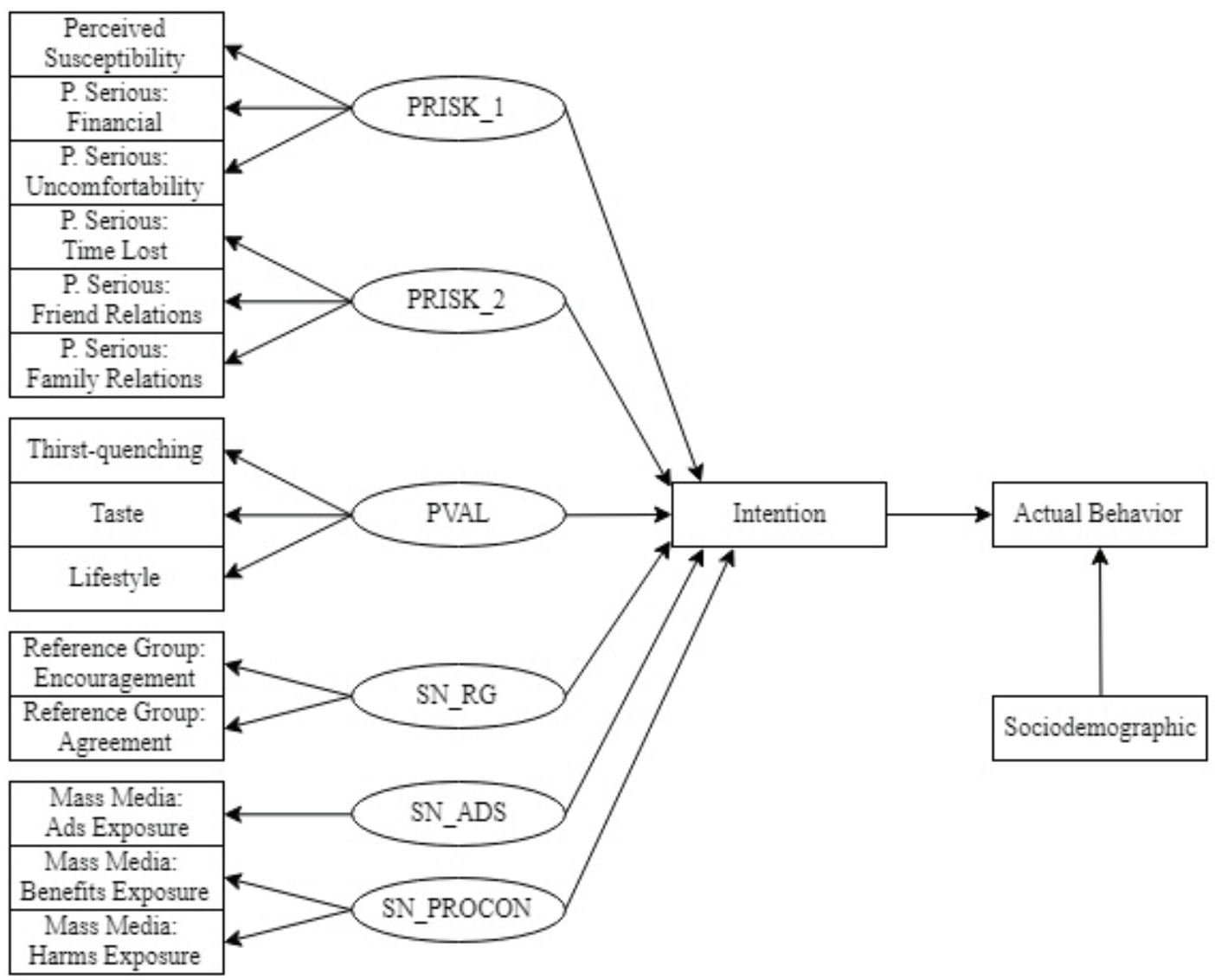

Figure 3: Full framework based on PCA result (new framework).

TABLE 4: Result from intention significance test using ordinal logit regression.

\begin{tabular}{l|c|c|c}
\hline Latent Variables (based on PCA) & Beta & P-value & Significance \\
\hline Perceived Risk 1(PRISK_1) & 0.159 & 0.174 & \\
\hline Perceived Risk 2 (PRISK_2) & -0.076 & 0.507 & \\
\hline Perceived Value (PVAL) & 1.089 & 0.000 & $*$ \\
\hline Subj. Norm: Reference Group (SN_RG) & 0.595 & 0.000 & $*$ \\
\hline Subj. Norm: Ads Exposure (SN_ADS) & -0.145 & 0.216 & \\
\hline Subj. Norm: Pro-Con Exp. (SN_PROCON) & -0.183 & 0.114 & \\
\hline "Significance found $(P \leq 0.05)$ & & &
\end{tabular}

both Ads Exposure and Product Benefits/Harms Exposure - does not affect the respondents' intention to buy the product. This means knowing more of sweetened packaged beverages' harms or thinking he/she had more risk consuming the product does not lessen the respondents' intention to buy the product, and neither seeing more advertisement or reading more about the products' benefit increase their intention to buy the product. 


\subsection{Actual behavior analysis}

We then tested intention and sociodemographic data toward actual behovior as the dependent variable by using OLS. The result from the test is presented in Table 5 .

TABLE 5: Result from actual behavior significance test using OLS.

\begin{tabular}{l|c|c|c|}
\hline Variables & Beta & p-value & Significance \\
\hline Intention & 0.409 & 0.000 & $*$ \\
\hline Gender & -0.119 & 0.043 & $*$ \\
\hline Age & -0.046 & 0.484 & \\
\hline Monthly Spending & 0.031 & 0.640 & \\
\hline \multicolumn{2}{|l|}{ "Significance found $(p \leq 0.05)$} & &
\end{tabular}

Intention and gender were found to significantly affect actual behavior. Intention has positive beta - which means it positively influence actual behavior, while gender had negative beta - which means male tends to actually consume the product more.

\section{Conclusion}

This research starts with the rise of sweetened packaged beverages in Indonesia, accompanied with the known health risk of sugar and media publishing on the topic. In the following literature research, it is found that reference group also affects intention besides of perceived risk, media and perceived value. From the issues the researcher formulated the objective of this research, which is to find out whether customers' perceived risk, perceived value, and subjective norm influences purchase intention, and consequently, purchase behavior on sweetened packaged beverages. To accomplish the research objective, we did a survey by using online questionnaire to collect data on the subject, which would be analyze further.

Based on the result of this research, it is found that intention to consume sweetened packaged beverages is significantly affected by perceived value (taste, thirstquenching, lifestyle/trending) and subjective norm from reference group - that is, perceived opinion of the people important for the respondents regarding consumption of the product. as Theory of Planned Behavior by Ajzen [31] stated, intention significantly affects actual behavior (the actual frequency of sweetened packaged beverages consumption). It is also found that males consume sweetened packaged beverages significantly more frequently than females, while age and monthly spending does not affect the behavior. 
This research also found that perceiving more risk in consuming the product, seeing more advertisement about sweetened packaged beverages' or reading more of the product harm or benefit does not affect intention to consume the product. This means, publishing the effects of sweetened packaged beverages or adding more ads for the product category does not affect consumption. These findings can be extended to future studies - whether the same outcome applies to other products.

It is important to note for sweetened packaged beverages producers that perceived value - thirst-quenching, taste, and trendy / lifestyle - is a strong determinant for Indonesians to consume the product. It is good news for the producers that consumers' perceived risk on consuming sweetened packaged beverages and articles on product harms (which are ubiquitous in news portals) does not significantly affect the intention. Producers are also recommended to advertise the products to males, and to utilize Reference Group in marketing sweetened packaged beverages, for example: advertising their products to consume with a group (for example, Marjan's advertisements that focus on consuming the product with family or friends).

This research found that knowing more about sweetened packaged beverages harms does not affect the intention to consume less sweetened packaged beverages. With this behavior in Indonesians, it can be hard for health officials or doctors to ask patients to avoid sweetened packaged beverage. This is relevant because type 2 diabetes - which is affected by sweetened beverages consumption - is the third cause of death by disease in Indonesia [41]. In order to reduce intention to consume the product, it is recommended to make public service advertisements that focus more on Reference Group aspect because of its significance on respondents' intention. For example, make the ads viewers to care more about their family health and then stimulate them to discourage their family members from consuming sweetened packaged beverages.

One of the shortcomings of this study is the low reliability of the variables to construct the latent variable, especially the media subjective norm. This may be due to the low number of study on the topic, thus precedent research papers that have robust framework is not available yet. Another limitation of this study is the lack of respondents' domicile control, making the data neither fully focused in cities (such as Jakarta / Bandung) nor represents Indonesia as a whole. Besides, there is nomenclature problem in describing the product in Indonesia. At the beginning of this research, we considered using the term 'sweetened beverages' instead of 'sweetened packaged beverages' because all kind of 'sweetened beverages' affect health and its harms are ubiquitous in many news portals. However, 'sweetened beverages' may extend to 
tea and coffee regularly drunk by Indonesian, because its customary to use sugar in these beverages. This can cause a problem when measuring the respondent's actual behavior or frequency in consuming the product, because brewing tea/coffee and buy packaged drink are quite distinct behaviors. It's also difficult to find the proper nomenclature classify brands such as Chatime, Dum Dum, or Hop Hop. Using the term 'sweetened packaged beverages' is ambiguous whether it describes these brands or not.

We recommend future studies to develop the research framework on the topic. This study only finds out perceived value and reference group as the strong predictors of intention to consume sweetened packaged beverages. Future studies may explore other factors that affect the people's intention or actual behavior in consuming the product. Future studies are also encouraged to find more proper nomenclature for the product because Indonesia's situation regarding sweetened beverages make describing the product complicated. Furthermore, research in the future is recommended to survey respondents in specific cities, so the research can be more useful by describing a city population's attitude regarding the product, rather than taking a sample from many cities without proportionate distribution.

\section{Appendix A: Survey Question List}

1. Perceived Risk (Likert)

(a) I have risk if I consume packaged sweetened beverages

(b) If I got ill because of consuming packaged sweetened beverages I will increase financial burden

(c) If I got ill because of consuming packaged sweetened beverages I will be uncomfortable

(d) If I got ill because of consuming packaged sweetened beverages I will lose time

(e) If I got ill because of consuming packaged sweetened beverages it will disturb my relationship with friends

(f) If I got ill because of consuming packaged sweetened beverages it will disturb my relationship with family

2. Perceived Value (Likert)

(a) I prefer thirst-quenching packaged sweetened beverage 
(b) I prefer packaged sweetened beverage that tastes good

(c) I would buy trending packaged sweetened beverage

3. Subjective Norm (Likert)

(a) Most people who are important to me approve of my engaging in this activity

(b) Most people who are important in my life think I should engage in this activity

(c) I frequently see/hear sweetened packaged beverages advertisement

(d) Article/News I read often states sweetened packaged beverages' harms

(e) Article/News I read often states sweetened packaged beverages' benefits

4. Intention (Likert)

(a) I often want to buy packaged sweetened beverage

5. Actual behavior* (Multiple choice)

(a) I buy packaged sweetened beverage...
i. $>2$ times a day
ii. 1-2 times a day
iii. 3-6 times a day
iv. 1-2 times a week
v. 1-3 times a month
vi. $<1$ time a month

6. Sociodemographic

(a) Gender (Multiple choice)
i. Male
ii. Female

(b) Age (Numeric entry)

(c) Monthly spending** (Multiple choice)
i. $<\operatorname{Rp} 1.500 .000$
ii. Rp 1.500.000 - Rp 2.500.000
iii. Rp 2.500.000 - Rp 5.000.000
iv. Rp 5.000.000 - Rp 10.000.000
v. Rp 10.000.000 - Rp 20.000.000 


$$
\text { vi. > Rp 20.000.000 }
$$

Notes:

*Actual Behavior data is converted to interval data by taking the midpoint from each interval. Interval data for the highest and lowest choice are offset from the written choice. The data from the multiple choices are converted to monthly consumption, which are 105, $45,18,6,2$, and 0.5 respectively

: Monthly spending dato is converted to interval dato by taking the midpoint from each interval. Interval data for the highest and lowest choice are offset from the written choice. The data from the multiple choices are converted to units of million IDR, which are $1,2,3.75,7.5,15$, and 30 respectively.

\section{References}

[1] THE MINUTE MAID Company, "History | Minute Maid ${ }^{\circledR}$ Indonesia," 2017. [Online]. Available: http://www.minutemaid.co.id/id/history/\#year2008. [Accessed 11 November 2017].W432W8784

[2] Wings Indonesia, "Wings Indonesia," 2016. [Online]. Available: http:// wingscorp.com/content/story.php?l=1\&m=309\&ul=4. [Accessed 11 November 2017].W432W8784

[3] T. Soeriaatmadja, "Luwak White Coffee - YouTube," 2012. [Online]. Available: https://www.youtube.com/watch?v=1dyY_i4LC88. [Accessed 11 November 2017].W432W8784

[4] Cimigo Indonesia, "TOP coffee - nostalgia in a coffee cup Indonesia, Asia Cimigo market research news," 2016. [Online]. Available: http://www.cimigo.com/ en/news-events/top-coffee-nostalgia-coffee-cup-indonesia-asia. [Accessed 11 November 2017].W432W8784

[5] OT, "Teh Gelas," 2017. [Online]. Available: http://www.tehgelas.com/wpcontent/uploads/2017/02/201703-ACC-timeline.jpg. [Accessed 11 November 2017].W432W8784

[6] F. F. Daulay, "Teh Pucuk Harum di Pameran UMKM PRSU - Tribun Medan," 2011. [Online]. Available: http://medan.tribunnews.com/2011/07/06/teh-pucuk-harumdi-pameran-umkm-prsu. [Accessed 11 November 2017].W432W8784

[7] J. J. DiNicolantonio, J. H. O'Keefe and S. C. Lucan, "Added Fructose: A Principal Driver of Type 2 Diabetes Mellitus and Its Consequences," Mayo Clinic Proceedings, vol. 90, no. 3, pp. 372-381, 2015. W432W8784 
[8] M. Maersk, A. Belza, H. Stødkilde-Jørgensen, S. Ringgaard, E. Chabanova, H. Thomsen, S. B. Pedersen, A. Astrup and B. Richelsen, "Sucrose-sweetened beverages increase fat storage in the liver, muscle, and visceral fat depot: a 6mo randomized intervention study.," The American Journal of Clinical Nutrition, vol. 95, no. 2, Pp. 283-9, 2012. W432W8784

[9] V. S. Malik, B. M. Popkin, G. A. Bray, J.-P. Després, W. C. Willett and F. B. Hu, "SugarSweetened Beverages and Risk of Metabolic Syndrome and Type 2 Diabetes," Diabetes Care, vol. 33, no. 11, pp. 2477-2483, 2010. W432W8784

[10] M. B. Schulze, J. E. Manson, D. S. Ludwig, G. A. Colditz, M. J. Stampfer, W. C. Willett and F. B. Hu, "Sugar-sweetened beverages, weight gain, and incidence of type 2 diabetes in young and middle-aged women," JAMA, vol. 292, no. 8, pp. 927-934, 2004. W432W8784

[11] World Health Organization, "Sugars intake for adults and children," 2015.W432W8784

[12] A. A. Ikhsania, "Tak Lagi Orangtua, Generasi Muda Rentan Menderita Diabetes, Ini Penyebab Utamanya!: Okezone Lifestyle," 2017. [Online]. Available: https://lifestyle.okezone.com/read/2017/11/02/481/1807157/tak-lagi-orangtuagenerasi-muda-rentan-menderita-diabetes-ini-penyebab-utamanya. [Accessed 17 November 2017].W432W8784

[13] F. D. Kusumaningrum, "Tak hanya bikin diabetes, ini efek mengerikan lain akibat makan gula | merdeka.com," 2017. [Online]. Available: https: //www.merdeka.com/sehat/tak-hanya-bikin-diabetes-ini-efek-mengerikanlain-akibat-makan-gula.html. [Accessed 17 November 2017].W432W8784

[14] Goldokter, "4 Teh yang Berkhasiat Bantu Menurunkan Gula Darah - Tribunnews.com," 2017. [Online]. Available: http://www.tribunnews.com/tribunners/ 2017/11/o6/4-teh-yang-berkhasiat-bantu-menurunkan-gula-darah. [Accessed 17 November 2017].W432W8784

[15] Kompas.com, "Gula, Penyebab Utama Diabetes dan Obesitas - Kompas.com," 2015. [Online]. Available: http://lifestyle.kompas.com/read/2015/02/03/ 121000223/Gula.Penyebab.Utama.Diabetes.dan.Obesitas. [Accessed 17 November 2017].W432W8784

[16] C. Hodgson, P. Lindsay and F. Rubini, "Can Mass Media Influence Emergency Department Visits for Stroke?," Stroke, vol. 38, no. 7, pp. 2115-2122, 2007. W432W8784

[17] R. Grilli, C. Ramsay and S. Minozzi, "Mass media interventions: effects on health services utilisation," Cochrane Database of Systematic Reviews, 2002. W432W8784 
[18] M. A. Wakefield, B. Loken and R. C. Hornik, "Use of mass media campaigns to change health behaviour," The Lancet, vol. 376, no. 9748, pp. 1261-1271, 2010. W432W8784

[19] D. J. Terry and M. A. Hogg, "Group Norms and the Attitude-Behavior Relationship: A Role for Group Identification," Personality and Social Psychology Bulletin, vol. 22, no. 8, pp. 776-793, 1996. W432W8784

[20] A. Åstrøm and J. Rise, "Young adults' intention to eat healthy food: Extending the theory of planned behaviour," Psychology \& Health, vol. 16, no. 2, pp. 223-237, 2001. W432W8784

[21] K. L. Johnston and K. M. White, "Binge-Drinking: A Test of the Role of Group Norms in the Theory of Planned Behaviour," Psychology \& Health, vol. 18, no. 1, pp. 63-77, 2003. W432W8784

[22] R. Cohen, "Sugar," 2013. [Online]. Available: http://ngm.nationalgeographic.com/ 2013/o8/sugar/cohen-text. [Accessed 20 November 2017].W432W8784

[23] USDA FAS, "Sugar: World Market and Trade," November 2017. [Online]. Available: https://apps.fas.usda.gov/psdonline/circulars/sugar.pdf. [Accessed 20 November 2017].W432W8784

[24] B. Higman, Jamaica Surveyed: Plantation Maps and Plans of the Eighteenth and Nineteenth Centuries, Jamaica: University of the West Indies Press, 2001. W432W8784

[25] FAO, "FAOSTAT," 2017. [Online]. Available: http://www.fao.org/faostat/en/\#data/ QC. [Accessed 20 November 2017].W432W8784

[26] USDA ERS, "Economic Research Service of United States Department of Agriculture," 1 June 2015. [Online]. Available: http://www. ers.usda.gov/datafiles/Sugar_and_Sweeteners_Yearbook_Tables/

US_Consumption_of_Caloric_Sweeteners_table50.xls. [Accessed 20 November 2017].W432W8784

[27] J. J. DiNicolantonio, S. C. Lucan and J. H. O'Keefe, "The Evidence for Saturated Fat and for Sugar Related to Coronary Heart Disease," Progress in Cardiovascular Diseases, vol. 58, no. 5, Pp. 464-472, 2016. W432W8784

[28] G. Hochbaum, I. Rosenstock and S. Kegels, "Health belief model," United States Public Health Service, 1952. W432W8784

[29] V. A. Zeithaml, "Consumer Perceptions of Price, Quality, and Value: A Means-End Model and Synthesis of Evidence," Journal of Marketing, vol. 52, no. 3, Pp. 2-22, 1988. W432W8784 
[30] C.-L. Hsu and J. C.-C. Lin, "What drives purchase intention for paid mobile apps? - An expectation confirmation model with perceived value," Electronic Commerce Research and Applications, vol. 14, no. 1, pp. 46-57, 2015. W432W8784

[31] I. Ajzen, "The theory of planned behavior," Organizational Behavior and Human Decision Processes, pp. 179-211, 1991. W432W8784

[32] A. C. Gunther, D. Bolt, D. L. G. Borzekowski, J. L. Liebhart and J. P. Dillard, "Presumed Influence on Peer Norms: How Mass Media Indirectly Affect Adolescent Smoking," Journal of Communication, vol. 56, no. 1, Pp. 52-68, 2006. W432W8784

[33] K. L. L'Engle, J. D. Brown and K. Kenneavy, "The mass media are an important context for adolescents' sexual behavior," Journal of Adolescent Health, vol. 38, no. 3, pp. 186-192, 2006. W432W8784

[34] S. D. Simon, "P.Mean," 2004. [Online]. Available: http://www.pmean.com/o4/ OrdinalLogistic.html. [Accessed 16 May 2018].W432W8784

[35] S. J. Walters, "Sample size and power estimation for studies with health related quality of life outcomes: a comparison of four methods using the SF-36," Health and Quality of Life Outcomes, vol. 2, p. 26, 2004. W432W8784

[36] P. F. Belgiawan, J.-D. Schmöcker, M. Abou-Zeid, J. Walker and S. Fujii, "Modelling social norms: Case study of students' car purchase intentions," Travel Behaviour and Society, Pp. 12-25, 2017. W432W8784

[37] L. R. Fabrigar, D. T. Wegener, R. C. MacCallum and E. J. Strahan, "Evaluating the Use of Exploratory Factor Analysis in Psychological Research," Psychological Methods, vol. 4, no. 3, pp. 272-299, 1999. W432W8784

[38] J. D. Brown, "Likert items and scales of measurement?," Shiken: JALT Testing \& Evaluation SIG Newsletter, pp. 10-14, March 2011. W432W8784

[39] I. Mawardi, "Tribun Jabar," 2017. [Online]. Available: http://jabar.tribunnews.com/ 2017/11/17/ridwan-kamil-upah-minimum-kota-bandung-naik-87-persen-jadirp-309-juta. [Accessed 22 May 2018].W432W8784

[40] I. Defianti, "Liputan6.com," 2017. [Online]. Available: https://www.liputan6.com/ news/read/3148203/anies-ump-dki-2018-perhitungkan-kepentingan-buruhdan-pengusaha. [Accessed 22 May 2018].W432W8784

[41] WHO, "World Health Organization - Diabetes country profiles, 2016," 2016. [Online]. Available: http://www.who.int/diabetes/country-profiles/idn_en.pdf. [Accessed 25 May 2018].W432W8784 